\title{
ANALISIS FAKTOR-FAKTOR YANG MEMPENGARUHI PENERIMAAN DAN PENGGUNAAN APLIKASI DOMPET DIGITAL MENGGUNAKAN TECHNOLOGY ACCEPTANE MODEL (TAM)
}

\author{
Zuraida Yuniar Firdaus ${ }^{1)}$, Dwi Krisbiantoro ${ }^{2)}$, Fiby Nur Afiana ${ }^{3)}$ \\ 1), 2), 3) Sistem Informasi Universitas AMIKOM Purwokerto \\ email : zuraidafirdaus9966@gmail.com ${ }^{1)}$,dwikris@amikompurwokerto.ac.id ${ }^{2}$, \\ fiby@amikompurwokerto.ac.id ${ }^{3)}$
}

\begin{abstract}
Abstraksi
Era revolusi industry 4.0 mendorong perkembangan teknologi dengan konsep Internet of Thing (IoT), bentuk penerapan IoT adalah penggunaan dompet digital sebagai alat pembayaran dalam kebutuhan bertransaksi. Salah satu dompet digital yang tengah berkembang di kalangan masyarakat adalah aplikasi DANA, dimana DANA memberikan kemudahan bertransaksi dengan lebih cepat dan praktis, serta memungkinkan pengguna melakukan pembayara nontunai dan tanpa kartu untuk kebutuhan sehari-hari. Beberapa pengguna DANA mengeluhkan adanya permasalahan kegagalan verifikasi identitas pengguna. Penelitian ini dilakukan dengan tujuan untuk menganalisis factor-faktor penerimaan dan penggunaan aplikasi DANA menggunakan pendekatan technology acceptance model TAM) dengan menambahkan variabel mobile payment characteristic sebagai variabel independent. Dari hasil penelitian diperoleh bahwa mobile payment characteristic secara simultan memiliki pengaruh terhadap penerimaan dan penggunaan aplikasi DANA.
\end{abstract}

\section{Kata Kunci:}

Dompet Digital, Karakteristik Pembayaran Seluler, Technologi Acceptane Model, DANA

\begin{abstract}
The era of the industrial revolution 4.0 encourages the development of technology with the concept of the internet of things (IoT), the form of IoT application is the use of digital wallets as a means of payment for transaction needs. One of the digital wallets that is currently developing among the public is the DANA application, where DANA provides convenience for faster and more practical transactions, and allows users to make non-cash and card less payments for their daily needs. Some DANA users have complained of problems with user identity verification failure. This study was conducted with the aim of analyzing the acceptance factors and the use of the DANA application using the technology acceptance model (TAM) approach by adding the mobile payment characteristic variable as an independent variable. From the results of the study, it was found that the mobile payment characteristic partially has an influence on the acceptance and use of the DANA application.
\end{abstract}

\section{Keywords:}

Digital Wallet, Mobile payment characteristic, Technologi Acceptane Model, DANA

\section{Pendahuluan}

Perkembangan teknologi di era Revolusi Industri 4.0 mengusung konsep Internet of Thing, dimana IoT memiliki kemampuan dalam menghubungkan dan memudahkan proses komunikasi antara mesin, perangkat, sensor, dan manusia melalui jaringan internet. Salah satu contoh penerapan IoT yaitu kemudahan dalam melakukan pembayaran dan mengirim uang dimana saja dan kapan saja dengan menggunakan aplikasi yang diinstall pada perangkat pengguna yang terhubung internet [1]

Di Indonesia sendiri telah banyak aplikasi dompet digital atau $e$-wallet yang ditawarkan kepada masyarakat. Salah satu aplikasi dompet digital yang umum digunakan masyarakat adalah DANA. Aplikasi Dana didirikan pada tahun 2017 sebagai hasil pengembangan dari PT Espay Debit Indonesia
Koe (EDIK) yang telah memiliki izin resmi, telah dilisensikan oleh Bank Indonesia sebagai e-money, $e$-wallet, serta layanan keuangan digital [2]. Pada pertengahan tahun 2021, layanan dompet digital mencatatkan pertumbuhan yang signifikan seiring dengan peningkatan jumlah transaksi nontunai di masa pandemi Covid19. Namun masih banyak pengguna yang mengalami permasalahan saat menggunakan aplikasi ini. Salah satu masalah yang dialami pengguna adalah kegagalan dalam proses verifikasi identitas ketika ingin meningkatkan akun dana menjadi akun premium. Permasalahan yang muncul dapat mempengaruhi penerimaan masyarakat terhadap penggunaan aplikasi dana.

Untuk mengetahui faktor yang dapat mempengaruhi penerimaan pengguna terhadap aplikasi Dana, maka dibutuhkan penelitian lebih lanjut mengenai analisis 
faktor-faktor yang mempengaruhi penerimaan dan penggunaan aplikasi Dana. Penelitian yang akan dilakukan ini memodifikasi model TAM dengan menambahkan variabel Mobile payment characteristics menurut [3] yang terdiri dari mobility, reachability, compatibility, dan convenience untuk menentukan faktor-faktor penerimaan dan penggunaan aplikasi Dana. Penelitian ini bertujuan untuk mengetahui faktorfaktor yang dapat mempengaruhi penerimaan dan penggunaan mobile aplikasi Dana serta mendapatkan informasi yang bermanfaat bagi masyarakat untuk merekomendasikan Dana sebagai aplikasi dompet digital.

\section{Tinjauan Pustaka}

1. Dompet Digital (E-Wallet)

Dompet digital atau sering disebut E-Wallet adalah bentuk financial technology yang merupakan metode pembayaran melalui media internet. Dompet digital secara umum dikatakan sebagai produk layanan uang elektronik berbasis chip dan server. Dompet digital berbasis chip biasanya berbentuk kartu seperti $E$ Money, Flazz dan Brizzi, sedangkan dompet digital berbasis server umumnya berbentuk aplikasi seperti goPay, OVO dan Dana. Penelitian terbaru dari Neurosensum menunjukkan bahwa masyarakat Indonesia semakin terbiasa dengan dompet digital [2].

\section{Aplikasi Dana}

Dana adalah dompet digital (e-wallet) Indonesia untuk semua transaksi cashless dan cardless yang dapat diandalkan kapan saja dan dimana saja. Saat ini, jumlah pengguna aplikasi Dana telah mencapai lebih dari 79 juta hingga akhir Juli 2021. Dengan aplikasi all-in-one, pengguna dapat dengan nyaman melakukan pembayaran tanpa uang tunai dan tanpa kartu untuk kebutuhan sehar-hari seperti pembelian offline, isi ulang pulsa, dan pembayaran tagihan [4].

\section{Technology Acceptance Model}

Technology Acceptance Model (TAM) merupakan salah satu model yang dapat digunakan untuk menganalisis faktor-faktor yang mempengaruhi penerimaan sistem informasi. Model ini pertama kali diperkenalkan oleh Fred Davis pada tahun 1986. TAM memiliki dua sisi yaitu sisi pertama atau sering disebut believes yang terdiri atas kegunaan (perceived usefulness) dan kemudahan penggunaan (Perceived ease of use) dan sisi kedua yang terdiri dari attitude, behavior intention to use dan usage behavior [5] [6].

TAM bertujuan untuk menjelaskan faktor-faktor utama dari perilaku pengguna terhadap penerimaan pengguna teknologi. Model ini menempatkan pengguna (usage) sebagai dependen variabel, serta perceived usefulness (PU) dan Perceived ease of use (PEOU) sebagai independent variabel. Kedua variabel independent dianggap dapat menjelaskan perilaku penggunaan.

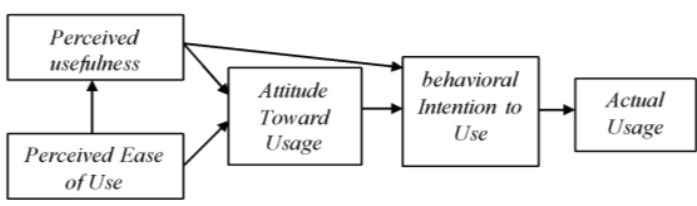

Gambar 1 Model TAM [6]

Berdasarkan gambar 1 dapat dijelaskan sebagai berikut [7]:

a. Persepsi kegunaan (perceived usefulness), didefinisikan sebagai sejauh mana seseorang percaya bahwa menggunakan suatu teknologi akan meningkatkan kinerjanya.

b. Persepsi kemudahan pengguna (Perceived ease of use), didefinisikan sebagai sejauh mana seseorang percaya bahwa penggunaan suatu teknologi akan bebas dari usaha.

c. Sikap terhadap penggunaan teknologi (attitude toward using), didefinisikan sebagai evaluasi dari pemakai tentang ketertarikannya dalam menggunakan teknologi.

d. Minat perilaku menggunakan teknologi (behavioral intention to use), didefinisikan sebagai minat atau keinginan seseorang untuk melakukan perilaku tertentu.

e. Penggunaan teknologi sesungguhnya (actual technology usage), diukur dengan jumlah waktu yang digunakan untuk berinteraksi dengan teknologi dan frekuensi pengguna teknologi tersebut.

4. Mobile payment characteristics

Berdasarkan penelitian yang dilakukan oleh [3], karakteristik mobile payment dibagi menjadi empat yaitu mobility, reachability, compatibility, dan convenience.

a. Mobility (mobilitas/pergerakan), "mobility adalah penentu yang digunakan untuk mengukur sejauh mana seeorang merasakan manfaat yang diterima dalam konteks waktu, ruang, dan akses layanan"'[8].

b. Reachability (keterjangkauan), reachability adalah layanan seluler yang disediakan oleh penyedia layanan yang dapat dijangkau dengan mudah oleh pengguna perangkat seluler [3].

c. Compatibility (kesesuaian), konsistensi kebiasaan dan keyakinan calon pengguna dengan teknologi yang akan diadopsi tampaknya sesuai dengan keyakinan bahwa teknologi ini mungkin lebih bermanfaat bagi pengguna dibandingkan dengan teknologi lain yang mungkin tidak sesuai dengan gaya hidup mereka [9].

d. Convenience (kenyamanan), "kenyamanan adalah kombinasi dari kepuasan waktu dan tempat" menurut [3]. Kenyamanan adalah faktor yang sangat penting untuk fungsi pembayaran seluler. Nilai emosional adalah utilitas yang berasal dari 
perasaan atau keadaan afektif yang dihasilkan oleh mobile payment.

\section{Metode Penelitian}

Penelitian ini dilakukan dengan langkah-langkah seperti gambar 2:

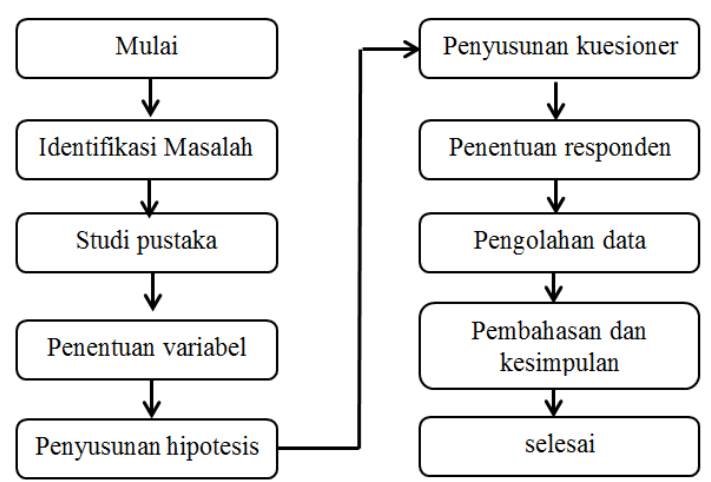

Gambar 2 Konsep Penelitian

\section{Identifikasi Masalah}

Tahapan identifikasi masalah ini dilakukan dengan cara menentukan titik permasalahan yang ada pada penggunaan aplikasi Dana, kemudian langkah selanjutnya adalah menganalisis penyelesaian dari permasalahan tersebut.

\section{Studi Pustaka}

Studi pustaka dilakukan dengan melakukan kajian terhadap jurnal penelitian sebelumnya, literatur dari buku serta pencarian di internet untuk mendapatkan referensi bagi penelitian ini.

\section{Penentuan Variabel Penelitian}

Pada tahapan ini dihasilkan jumlah variabel yang akan digunakan dalam penelitian ini, yaitu sebagai berikut: perceived usefulness, perceived ease of use, behavioral intention, dan attitude toward using. Serta variabel independen adalah mobile payment characteristic yaitu mobility, reachability, compatibility, dan convenience.

\section{Penyusunan hipotesis}

Pada tahap ini didapatkan kerangka berpikir bahwa Apabila mobile payment dapat meningkatkan kinerja pengguna dan mudah dipahami, maka pengguna dapat merasakan manfaat mobile payment. Hal tersebut akan memengaruhi sikap pengguna, serta dapat mempengaruhi niat penggunaan mobile payment tersebut. Kerangka berpikir digambarkan dalam model penelitian berikut:

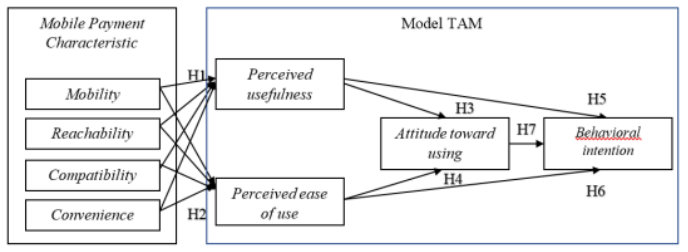

Gambar 3 Model penelitian

Berdasarkan gambar 3 maka didapatkan rumusan hipotesis penelitian sebagai berikut:

a. Mobility, reachability, compatibility, convenience berpengaruh terhadap perceived usefulness

b. Mobility, reachability, compatibility, convenience berpengaruh terhadap perceived ease of use.

c. Perceived ease of use berpengaruh terhadap attitude toward using.

d. perceived usefulness berpengaruh terhadap attitude toward using.

e. perceived usefulness berpengaruh terhadap behavior intention.

f. Perceived ease of use berpengaruh terhadap behavior intention.

g. attitude towards using berpengaruh terhadap behavioral intention.

\section{Penyusunan Kuesioner}

Pada tahap ini dilakukan penyusunan daftar pertanyaan yang akan dibagikan kepada responden. Terdapat 22 butir pertanyaan yang digunakan pada penelitian ini.

\section{Penentuan Responden}

Pada tahap ini dilakukan penentuan seberapa banyak responden yang akan terlibat dalam penelitian. Responden diperoleh menggunakan rumus slovin [10]

Keterangan:

$$
n=\frac{N}{1+N\left(e^{2}\right)}
$$

$\mathrm{n}$ : besar sampel

$\mathrm{N}$ : jumlah populasi

e: error margin (dalam penelitian ini tingkat kesalahan $10 \%$ atau 0,1 )

\section{Pengolahan Data}

a. Uji validitas

Uji validitas bertujuan untuk mengukur sejauh mana variabel yang digunakan benar-benar mengukur apa yang hendak diukur[11]. Pengukuran validitas dalam penelitian ini menggunakan uji statistik korelasi product moment. Dasar pengambilan keputusan pada uji validitas sebagai berikut:

1) Apabila nilai $R$ hitung $>R$ table maka dinyatakan valid.

2) Apabila nilai $R$ hitung $<R$ table maka dinyatakan tidak valid.

b. Uji Reliabilitas 
Uji reliabilitas adalah indeks yang menunjukkan sejauh mana pengukuran dapat dipercaya[11]. Kuesioner dikatakan reliabel berdasarkan rumus cronbach's apabila $r$ hitun lebih besar dari $r$ tabel ( $r$ hitung > r tabel), sebaliknya apabila $r$ hitung lebih kecil dari $\mathrm{r}$ table maka kuesioner dikatakan tidak reliabel.

c. Uji regresi linear berganda

Uji regresi linear berganda menyatakan suatu bentuk hubungan linear antara dua atau lebih variabel dependen dengan variabel independentnya.

1) Uji asumsi klasik

Syarat uji regresi linear yaitu pengujian asumsi, pada penelitian ini dilakukan uji asumsi antara lain uji normalitas, uji linearitas, uji multikolinearitas, dan uji heteroskedastisitas.

2) Uji hipotesis

Pada penelitian ini melakukan pengujian hipotesis antara lain:

a) uji koevisien determinasi

Koevisien determinasi yang dilihat adalah nilai dari adjusted $\mathrm{R}^{2}$ digunakan untuk mengetahui seberapa jauh variabel terikat. pengambilan keputusan dalam uji koevisien determinasi yaitu jika $R^{2}$ bernilai 1 maka ada kecocokan yang sempurna. Jika $\mathrm{R}^{2}$ bernilai 0 maka tidak ada hubungan antara variabel dependen dan independen.

b) uji parsial

Uji parsial atau uji T bertujuan untuk mengetahui seberapa jauh tiap-tiap variabel dependen berpengaruh secara individual terhadap variabel independent. Pengujian uji t dilakukan dengan membandingkan $\mathrm{t}$ hitung dengan $\mathrm{t}$ table pada derajat signifikan $10 \%$.

c) uji simultan.

Pengujian ini dilakukan untuk mengetahui pengaruh variabel independen secara bersamasama (simultan) terhadap variabel dependen. Pengambilan kesimpulan pada uji $\mathrm{F}$ dilakukan dengan membandingkan nilai $\mathrm{F}$ hitung dengan $\mathrm{F}$ table pada derajat signifikan 5\%.

\section{Pembahasan dan kesimpulan}

Tahapan ini adalah melakukan pembahasan mengenai hasil uji statistik yang telah dilakukan pada tahap sebelumnya, kemudian menarik kesimpulan berdasarkan hasil yang didapatkan

\section{Hasil dan Pembahasan}

Deskripsi Responden

Berdasarkan hasil perhitungan sampel dari jumlah populasi penduduk Banyumas yang tergolong dalam usia produktif yaitu usia 15 sampai 65 tahun sebanyak 1.225.244 orang. dengan error margin $10 \%$, maka responden yang dibutuhkan minimal 100 orang. Pada penelitian ini memperoleh 126 responden, setelah melalui proses pemilahan data diperoleh 105 data responden yang layak digunakan dalam penelitian. Deskripsi responden dijelaskan dalam tabel 1 berikut:

Tabel 1 Deskripsi responden

\begin{tabular}{|l|c|c|c|}
\hline \multicolumn{2}{|l|}{ Keterangan } & Jumlah & Presentase \\
\hline \multirow{2}{*}{$\begin{array}{l}\text { Jenis } \\
\text { Kelamin }\end{array}$} & Laki-laki & 42 & $40 \%$ \\
\cline { 2 - 4 } & Perempuan & 63 & $60 \%$ \\
\hline
\end{tabular}

Table 1 lanjutan

\begin{tabular}{|l|l|l|l|}
\hline \multicolumn{2}{|l|}{ Total } & 105 & $100 \%$ \\
\hline \multirow{4}{*}{ kelompok usia } & $15-24$ & 60 & $57.1 \%$ \\
\cline { 2 - 4 } & $25-34$ & 42 & $40 \%$ \\
\cline { 2 - 4 } & $35-44$ & 2 & $1.9 \%$ \\
\cline { 2 - 4 } & $45-54$ & 1 & $1 \%$ \\
\cline { 2 - 4 } & $55-64$ & 0 & $0 \%$ \\
\hline \multicolumn{2}{|l}{ Total } & 105 & $100 \%$ \\
\hline \multirow{2}{*}{$\begin{array}{l}\text { pengguna } \\
\text { Aplikasi Dana }\end{array}$} & Tidak & 105 & $100 \%$ \\
\hline \multirow{2}{*}{$\begin{array}{l}\text { Total } \\
\text { kelengkapan } \\
\text { Jawaban }\end{array}$} & Lengkap & 105 & $0 \%$ \\
\cline { 2 - 4 } & Tidak & 105 & $100 \%$ \\
\hline \multicolumn{2}{|l|}{ Total } & 0 & $0 \%$ \\
\hline
\end{tabular}

\section{Uji Instrumen Penelitian}

\section{Uji Validitas}

Dasar pengambilan keputusan pada uji validitas yaitu nilai $r$ Hitung lebih besar dari $r$ Table maka dinyatakan valid. Namun apabila nilai $r$ Hiitung lebih kecil dari $r$ Table maka dinyatakan tidak valid. Untuk menentukan $\mathrm{r}$ Tabel adalah $\mathrm{df}=\mathrm{N}-2$, maka nilai $\mathrm{df}=$ $100-2=98$. Dengan tingkat signifikan $(\alpha=1 \%)$ diperoleh $\mathrm{r}$ Tabel $=0,232$. Berdasarkan pengujian validitas diperoleh hasil sebagai berikut:

Tabel 2 Uji validitas

\begin{tabular}{|l|l|l|l|l|}
\hline \multirow{2}{*}{ Variabel } & Indikator & $\begin{array}{l}\text { Pearso } \\
\text { Correla } \\
\text { tion }\end{array}$ & $\begin{array}{l}\mathrm{r} \\
\text { Tabel } \\
\alpha=1 \%\end{array}$ & ket \\
\hline \multirow{3}{*}{ mobility } & Mobilityl & 0.851 & 0.232 & Valid \\
\cline { 2 - 5 } & Mobility2 & 0.867 & 0.232 & Valid \\
\hline \multirow{3}{*}{$\begin{array}{l}\text { lity } \\
\text { reachabi }\end{array}$} & $\begin{array}{l}\text { reachabili } \\
\text { tyl }\end{array}$ & 0.684 & 0.232 & Valid \\
\cline { 2 - 5 } & $\begin{array}{l}\text { reachabili } \\
\text { reachabili } \\
\text { ty3 }\end{array}$ & 0.739 & 0.232 & Valid \\
\cline { 2 - 5 } & $\begin{array}{l}\text { reachabili } \\
\text { ty4 }\end{array}$ & 0.844 & 0.232 & Valid \\
\hline $\begin{array}{l}\text { compati } \\
\text { bility }\end{array}$ & $\begin{array}{l}\text { compatibil } \\
\text { ityl }\end{array}$ & 0.805 & 0.232 & Valid \\
\hline
\end{tabular}


Firdaus dkk, Analisis Faktor-Faktor Yang Mempengaruhi Penerimaan Dan Penggunaan Aplikasi Dompet Digital Menggunakan Technology Acceptance Model (TAM)

\begin{tabular}{|c|c|c|c|c|}
\hline & $\begin{array}{l}\text { compatibil } \\
\text { ity } 2\end{array}$ & 0.847 & 0.232 & Valid \\
\hline & $\begin{array}{l}\text { compatibil } \\
\text { ity3 }\end{array}$ & 0.708 & 0.232 & Valid \\
\hline \multirow{3}{*}{$\begin{array}{l}\text { convenie } \\
\text { nce }\end{array}$} & $\begin{array}{l}\text { convenien } \\
\text { cel }\end{array}$ & 0.814 & 0.232 & Valid \\
\hline & $\begin{array}{l}\text { convenien } \\
\text { ce2 }\end{array}$ & 0.761 & 0.232 & Valid \\
\hline & $\begin{array}{l}\text { convenien } \\
\text { ce3 }\end{array}$ & 0.885 & 0.232 & Valid \\
\hline \multirow{3}{*}{$\begin{array}{l}\text { perceive } \\
d \\
\text { usefulne } \\
\text { ss }\end{array}$} & PU1 & 0.826 & 0.232 & Valid \\
\hline & $P U 2$ & 0.799 & 0.232 & Valid \\
\hline & PU3 & 0.875 & 0.232 & Valid \\
\hline \multirow{3}{*}{$\begin{array}{l}\text { perceive } \\
\text { d ease of } \\
\text { use }\end{array}$} & PEOU1 & 0.8 & 0.232 & Valid \\
\hline & PEOU2 & 0.765 & 0.232 & Valid \\
\hline & PEOU3 & 0.791 & 0.232 & Valid \\
\hline \multirow{2}{*}{$\begin{array}{l}\text { attitude } \\
\text { toward } \\
\text { using }\end{array}$} & $A T U 1$ & 0.829 & 0.232 & Valid \\
\hline & $A T U 2$ & 0.912 & 0.232 & Valid \\
\hline \multirow{2}{*}{$\begin{array}{l}\text { behavior } \\
\text { al } \\
\text { intention }\end{array}$} & $B I 1$ & 0.892 & 0.232 & Valid \\
\hline & $B I 2$ & 0.903 & 0.232 & Valid \\
\hline
\end{tabular}

2. Uji Reliabilitas

Hasil perhitungan uji reliabilitas dengan membandingkan nilai cronbach's alpha dengan koevisien reliabel 0.60 maka diperoleh hasil sebagainberikut:

Tabel 3 Uji Reliabilitas

\begin{tabular}{|c|c|c|c|l|}
\hline No & Variabel & $\begin{array}{c}\text { Cronbach's } \\
\text { Alpha }\end{array}$ & $\begin{array}{c}\mathrm{N} \\
\text { of } \\
\text { item }\end{array}$ & Ket \\
\hline 1 & Mobility & 0.644 & 2 & reliabel \\
\hline 2 & reachability & 0.762 & 4 & reliabel \\
\hline 3 & compatibility & 0.695 & 3 & reliabel \\
\hline 4 & convenience & 0.758 & 3 & reliabel \\
\hline 5 & $P U$ & 0.713 & 3 & reliabel \\
\hline 6 & $P E O U$ & 0.685 & 3 & reliabel \\
\hline 7 & $A T U$ & 0.669 & 2 & reliabel \\
\hline 8 & $B I$ & 0.758 & 2 & reliabel \\
\hline
\end{tabular}

Berdasarkan tabel 3 diperoleh bahwa terdapat 8 variabel pertanyaan yang disusun sebagai instrument penelitian, dan menghasilkan nilai cronbach's alpha lebih besar dari 0.60. sehingga disimpulkan bahwa pertanyaan yang disusun reliabel untuk digunakan.

3. Uji Asumsi Klasik

a) Uji Normalitas

\begin{tabular}{|c|c|c|c|c|}
\multicolumn{5}{|c}{ Tabel 4 Uji Normalitas } \\
\hline No & model & $\begin{array}{c}\text { Dependen } \\
\text { variabel }\end{array}$ & $\begin{array}{c}\text { Exact } \\
\text { Sig. (2- } \\
\text { tailed) }\end{array}$ & $\begin{array}{c}\text { Sig } \\
\cdot\end{array}$ \\
\hline 1 & $\begin{array}{l}\text { M-payment } \\
\text { characteristic }\end{array}$ & PU & .462 & $\begin{array}{c}0.0 \\
5\end{array}$ \\
\hline 2 & M-payment & PEOU & .751 & 0.0 \\
\hline
\end{tabular}

\begin{tabular}{|c|l|c|c|c|}
\hline & characteristic & & & 5 \\
\hline 3 & PU & ATU & .271 & $\begin{array}{c}0.0 \\
5\end{array}$ \\
\hline 4 & PEOU & ATU & .133 & $\begin{array}{c}0.0 \\
5\end{array}$ \\
\hline 5 & PU & BI & .020 & $\begin{array}{c}0.0 \\
5\end{array}$ \\
\hline 6 & PEOU & BI & .034 & $\begin{array}{c}0.0 \\
5\end{array}$ \\
\hline 7 & ATU & BI & .003 & $\begin{array}{c}0.0 \\
5\end{array}$ \\
\hline
\end{tabular}

Berdasarkan tabel pengujian normalitas data diperoleh kesimpulan bahwa nilai exact sig. 2tailled lebih besar dari 0.05, maka sebaran data dinyatakan normal. Terdapat sebaran data yang tidak normal, yaitu variable PU terhadap BI, PEOU terhadap BI, dan variabel ATU terhadap BI.

b) Uji multikolinearitas

Tabel 5 Uji Multikolinearitas

\begin{tabular}{|c|l|l|c|c|}
\hline \multirow{2}{*}{$\begin{array}{c}\mathrm{N} \\
\mathrm{o}\end{array}$} & \multirow{2}{*}{ Model } & $\begin{array}{l}\text { depend } \\
\text { en } \\
\text { variabe }\end{array}$ & $\begin{array}{c}\text { Collinearity } \\
\text { Statistics }\end{array}$ \\
\cline { 3 - 5 } & & $\begin{array}{c}\text { Toler } \\
\text { ance }\end{array}$ & VIF \\
\hline 1 & mobility & PU & .659 & 1.518 \\
\hline 2 & reachability & PU & .486 & 2.056 \\
\hline 3 & compability & PU & .444 & 2.252 \\
\hline 4 & convenience & PU & .410 & 2.437 \\
\hline 5 & mobility & PEOU & .659 & 1.518 \\
\hline 6 & reachability & PEOU & .486 & 2.056 \\
\hline 7 & compability & PEOU & .444 & 2.252 \\
\hline 8 & convenience & PEOU & .410 & 2.437 \\
\hline 9 & PU & ATU & 1.000 & 1.000 \\
\hline 10 & PU & BI & 1.000 & 1.000 \\
\hline 11 & PEOU & ATU & 1.000 & 1.000 \\
\hline 12 & PEOU & BI & 1.000 & 1.000 \\
\hline 13 & ATU & BI & 1.000 & 1.000 \\
\hline
\end{tabular}

Berdasarkan table 5 diperoleh hasil uji multikolinearitas dengan nilai tolerance $>0.01$ dan nilai VIF <10, maka disimpulkan bahwa tidak terdapat gejala multikolinearitas pada hubungan variable yang diuji.

c) Uji heteroskedastisitas

Tabel 6 Uji Heteroskedastisitas

\begin{tabular}{|c|l|l|l|l|}
\hline $\begin{array}{c}\mathrm{N} \\
\mathrm{o}\end{array}$ & \multicolumn{1}{|c|}{ Model } & $\begin{array}{c}\text { dependen } \\
\text { t variabel }\end{array}$ & Sig. & $\begin{array}{c}\text { taraf } \\
\text { signifi } \\
\text { kan }\end{array}$ \\
\hline 1 & mobility & PU & .001 & 0.05 \\
\hline 2 & reachability & PU & .507 & 0.05 \\
\hline 3 & compability & PU & .028 & 0.05 \\
\hline 4 & convenience & PU & .198 & 0.05 \\
\hline 5 & mobility & PEOU & .432 & 0.05 \\
\hline 6 & reachability & PEOU & .855 & 0.05 \\
\hline 7 & compability & PEOU & .582 & 0.05 \\
\hline 8 & convenience & PEOU & .078 & 0.05 \\
\hline 9 & PU & ATU & .379 & 0.05 \\
\hline 10 & PU & BI & .012 & 0.05 \\
\hline
\end{tabular}




\begin{tabular}{|l|l|l|l|l|}
\hline 11 & PEOU & ATU & .381 & 0.05 \\
\hline 12 & PEOU & BI & .727 & 0.05 \\
\hline 13 & $A T U$ & BI & .008 & 0.05 \\
\hline
\end{tabular}

Berdasarkan table 6 diperoleh nilai signifikan $>0.05$, maka disimpulkan bahwa terdapat masalah heteroskedastisitas pada hubungan variable mobility dan convenience terhadap PU, serta variabel PU dan ATU terhadap BI.

d) Uji linearitas

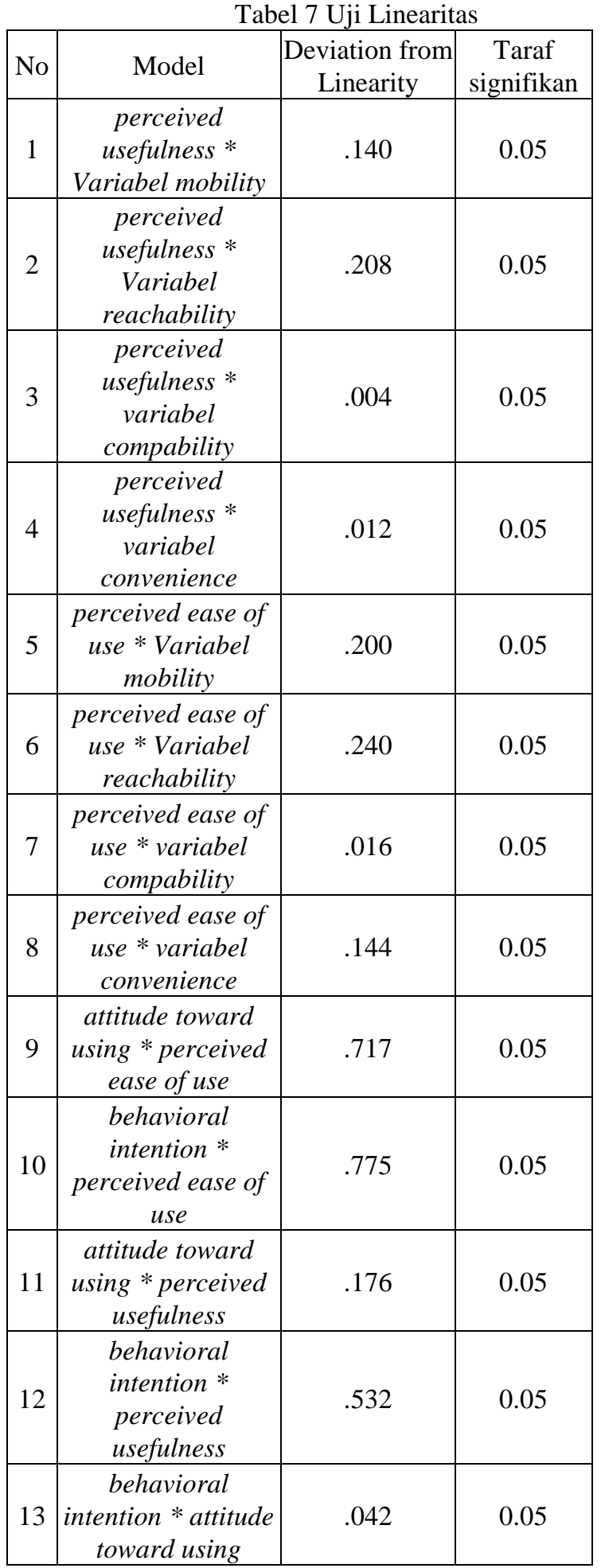

Berdasarkan table 6 diperoleh nilai signifikan >0.05, maka disimpulkan bahwa terdapat variabel yang tidak memiliki hubungan linear yaitu compatibility terhadap PU dan PEOU, convenience terhadap PU, serta ATU terhadap BI.

4. Uji Hipotesis

a) Uji koevisien determinasi

Tabel 8 Uji $\mathrm{r}^{2}$

\begin{tabular}{|c|l|l|c|c|}
\hline No & \multicolumn{1}{|c|}{ Model } & $\begin{array}{c}\text { dependent } \\
\text { variabel }\end{array}$ & $\mathrm{R}^{2}$ & $\%$ \\
\hline 1 & $\begin{array}{l}\text { m-payment } \\
\text { characteristic }\end{array}$ & PU & .324 & $32 \%$ \\
\hline 2 & $\begin{array}{l}\text { m-payment } \\
\text { characteristic }\end{array}$ & PEOU & .293 & $29 \%$ \\
\hline 3 & PU & ATU & .349 & $35 \%$ \\
\hline 4 & PU & BI & .316 & $32 \%$ \\
\hline 5 & PEOU & ATU & .134 & $13 \%$ \\
\hline 6 & PEOU & BI & .076 & $8 \%$ \\
\hline 7 & ATU & BI & .497 & $50 \%$ \\
\hline
\end{tabular}

Berdasarkan table 8 diperoleh hasil uji $\mathrm{R}^{2}$ untuk mengetahui seberapa jauh variabel berpengaruh terhadap variabel dependen. Prosentase tertinggi menunjukkan bahwa ATU berprngaruh 50\% terhadap BI dan sisanya dipengaruhi oleh vsrisbel lainnya.

b) Uji parsial

Tabel 9 Uji Parsial

\begin{tabular}{|r|l|l|r|c|}
\hline No & Model & $\begin{array}{l}\text { Dependen } \\
\text { variabel }\end{array}$ & $\begin{array}{c}\mathrm{t} \\
\text { Hitung }\end{array}$ & $\begin{array}{c}\mathrm{t} \\
\text { Tabel }\end{array}$ \\
\hline 1 & Mobility & PU & 0.285 & 1.664 \\
\hline 2 & $\begin{array}{l}\text { reachabilit } \\
\text { y }\end{array}$ & PU & 0.902 & 1.664 \\
\hline 3 & $\begin{array}{l}\text { compatibil } \\
\text { ity }\end{array}$ & PU & 3.169 & 1.664 \\
\hline 4 & $\begin{array}{l}\text { convenien } \\
\text { ce }\end{array}$ & PU & 0.832 & 1.664 \\
\hline 5 & Mobility & PEOU & 0.145 & 1.664 \\
\hline 6 & $\begin{array}{l}\text { reachabilit } \\
y\end{array}$ & PEOU & -0.319 & 1.664 \\
\hline 7 & $\begin{array}{l}\text { compatibil } \\
\text { ity }\end{array}$ & PEOU & 1.816 & 1.664 \\
\hline 8 & $\begin{array}{l}\text { convenien } \\
\text { ce }\end{array}$ & PEOU & 2.832 & 1.664 \\
\hline 9 & PEOU & ATU & 3.998 & 1.664 \\
\hline 10 & PEOU & BI & 2.916 & 1.664 \\
\hline 11 & PU & ATU & 7.429 & 1.664 \\
\hline 12 & PU & BI & 6.891 & 1.664 \\
\hline 13 & ATU & BI & 10.085 & 1.664 \\
\hline
\end{tabular}

Berdasarkan table 9 diperoleh hasil bahwa nilai $\mathrm{t}$ hitung > $\mathrm{t}$ tabel maka ada pengaruh variabel independen secara parsial terhadap variabel dependen. M-payment characteristic yang berpengaruh adalah compatibility berpengaruh 
terhadap PU dan PEOU, serta convenience berpengaruh terhadap PEOU. Sementara PU dan PEOU berpegaruh secara parsial terhadap ATU maupun BI.

c) Uji simultan

Nilai $\mathrm{F}$ tabel pada penelitian ini $\mathrm{F}=8 ;(105-8)=$ 8;97. Pada distribusi tabel $\mathrm{F}$ menunjukkan nilai 2,03. apabila nilai $\mathrm{F}$ hitung $>\mathrm{F}$ table maka variabel independent terdapat pengaruh secara simultan kepada variabel dependen.

Tabel 10 uji simultan

\begin{tabular}{|l|l|l|c|c|}
\hline No & Model & $\begin{array}{l}\text { dependent } \\
\text { variabel }\end{array}$ & $\begin{array}{c}\mathrm{f} \\
\text { Hitung }\end{array}$ & $\begin{array}{c}\mathrm{f} \\
\text { Tabel }\end{array}$ \\
\hline 1 & $\begin{array}{l}\text { m-payment } \\
\text { characterist } \\
\text { ic }\end{array}$ & PU & 12.006 & 2.03 \\
\hline 2 & $\begin{array}{l}\text { m-payment } \\
\text { characterist } \\
\text { ic }\end{array}$ & PEOU & 10.347 & 2.03 \\
\hline 3 & $\begin{array}{l}\text { PU dan } \\
\text { PEOU }\end{array}$ & ATU & 23.588 & 2.03 \\
\hline 4 & $\begin{array}{l}\text { PU dan } \\
\text { PEOU }\end{array}$ & BI & 27.788 & 2.03 \\
\hline
\end{tabular}

Berdasarkan table 9 diperoleh hasil bahwa nilai $\mathrm{f}$ hitung > $\mathrm{f}$ tabel maka ada pengaruh variabel independen secara bersama terhadap variabel dependen. Maka dapat disimpulkan bahwa m-payment characteristic berpengaruh secara simultan dan signifikan terhadap PU dan PEOU, sementara variabel PU dan PEOU secara bersama-sama mempengaruhi ATU dan BI.

\section{Kesimpulan dan Saran}

Berdasarkan hasil penelitian analisis faktor-faktor yang mempengaruhi penerimaan dan penggunaan aplikasi dompet digital menggunakan model Technology Acceptance Model (TAM) dengan objek penelitian aplikasi DANA, maka diperoleh kesimpulan sebagai berikut.

1. Hasil uji $\mathrm{T}$ menyatakan bahwa karakteristik mobile payment tidak berpengaruh secara parsial terhadap variabel TAM. Hasil uji F menunjukkan mobile payment characteristic berpengaruh secara simultan dan signifikan terhadap persepsi kegunaan dan persepsi kemudahan penggunaan aplikasi DANA.

2. Niat dan perilaku aplikasi penggunaan aplikasi Dana dipengaruhi oleh manfaat aplikasi serta tingkat kemudahan dalam penggunaan aplikasi tersebut. Dalam kasus ini aplikasi Dana sebagai dompet digital, faktor mobile payment characteristic akan berpengaruh secara bersamasama terhadap penerimaan dan penggunaan aplikasi oleh masyarakat.

Saran yang dapat diberikan berdasarkan hasil penelitian ini bagi penelitian selanjutnya adalah memperluas cakupan wilayah dan menambah jumlah responden, serta dapat menggunakan metode analisis selain regresi linear berganda. Bagi pengembang aplikasi dompet digital untuk mempertimbangan karakteristik mobile paymen yaitu mobilitas, keterjangkauan, kesesuaian, serta kenyamanan penggunaan aplikasi, karena karakteristik mobile paymen dapat mempengaruhi tingkat penerimaan pada pengguna.

\section{Daftar Pustaka}

[1] L. Baenanda, "Mengenal lebih jauh revolusi industri 4.0.," binus.ac.id, 2019. .

[2] Tempo, "Persaingan 5 domepet digital berebut pasar di masa pandemi Covid-19.," bisnis.tempo.co, 2021. .

[3] C. Kim, M. Mirusmonov, and I. Lee, "An empirical examination of factors influencing the intention to use mobile payment," Comput. Human Behav., vol. 26, no. 3, pp. 310-322, 2010, doi: 10.1016/j.chb.2009.10.013.

[4] Dana.id, "Tentang dana," 2021. .

[5] Y. Oktapiani, M. Rosario, and A. Nehemia, "Analisis Minat Penggunaan Aplikasi Brimo Dengan Pendekatan Technology Acceptance Model ( TAM )," Ilm. Mhs. Sist. Inf., vol. 2, no. 3, pp. 249-260, 2020.

[6] F. D. Davis, "Perceived usefulness, perceived ease of use, and user acceptance of information technology," MIS Q. Manag. Inf. Syst., 1989, doi: 10.2307/249008.

[7] Y. M. Gerhana, "Implementasi technology acceptance model untuk mengukur penerimaan guru terhadap inovasi pembelajaran(studi kasus model pembelajaran CBR di SMK)," J. Istek, vol. 10, no. 2, pp. 1-18, 2017.

[8] G. Tai, P.T \& liu, "An analysis of factors affecting the intention to use mobility payment services in Vietnam.," Proc. Second Asia-Pacific Conf. Glob. Business, Econ. Financ., vol. V574, pp. 1-21, 2015.

[9] G. Wang, N. M. Putri, and A. Christianto, "An empirical examination of characteristic," J. Theor. Appl. Inf. Technol., vol. 96, no. 1, pp. 169-182, 2019.

[10] Hardani et al., Buku Metode Penelitian Kualitatif dan Kuantitatif, no. March. 2015.

[11] J. Sarwono, Analisis data penelitian menggunakan SPSS. yogyakarta: andi offset, 2006. 